Article

\title{
The Recovery of Ca and Zn from the Municipal Solid Waste Incinerator Fly Ash
}

\author{
Chen-Piao Yen, Song-Yan Zhou and Yun-Hwei Shen *(D) \\ Department of Resources Engineering, National Cheng Kung University, Tainan 70101, Taiwan; \\ cat5@mail.tainan.gov.tw (C.-P.Y.); zxc2573841@gmail.com (S.-Y.Z.) \\ * Correspondence: yhshen@mail.ncku.edu.tw
}

Received: 7 September 2020; Accepted: 29 October 2020; Published: 31 October 2020

check for updates

\begin{abstract}
The treatment and disposal of municipal solid waste incineration (MSWI) fly ash containing significant amounts of dissolvable salts and heavy metals is a seriously challenge. At present, the common treatment method for MSWI fly ash in Taiwan is the cement-based stabilization/solidification (S/S) process. In this work, an integrated hydrometallurgical process for the treatment of MSWI fly ash was evaluated. Ca was first recovered by combining water washing and ion exchange sequentially. Meanwhile, $\mathrm{Zn}$ in the water-washed fly ash was recovered by combining acid leaching and ion exchange sequentially. Combining the water washing efficiency of $30 \%$ on raw ash and the acid leaching efficiency of $40 \%$ on pre-washed ash, a total of $58 \%$ mass reduction rate of fly ash was achieved. In addition, an $80 \% \mathrm{Zn}$ and $58 \%$ Ca recovery was achieved.
\end{abstract}

Keywords: fly ash; washing; leaching; ion exchange; calcium; zinc

\section{Introduction}

Incineration is one of the efficient methods in current waste treatment techniques and is capable of achieving volume reduction. In Taiwan, there have been 24 municipal solid waste incinerator (MSWI) plants in operation up to now and 6.24 million tons of waste was treated annually. After incineration, one-fifth of the weight of the MSW becomes residues and $23 \mathrm{wt} . \%$ of the residues is fly ash. In this manner, 302,000 tons of the MSWI fly ash are produced in Taiwan annually [1]. In recent years, MSWI has also become a popular method to treat MSW in Japan and several European countries due to the merits of volume reduction [2,3] and energy recovery [4,5]. MSWI fly ash contains chloride salts, dioxins, and heavy metals, such as zinc $(\mathrm{Zn})$, lead $(\mathrm{Pb})$, copper $(\mathrm{Cu}$,$) and Cadmium (\mathrm{Cd})$ and is considered as a hazardous waste [6]. $\mathrm{CaO}$ or $\mathrm{CaCO}_{3}$ are injected into the furnace to neutralize the emission of acid gases such as $\mathrm{HCl}$ and $\mathrm{SO}_{\mathrm{x}}$ during MSW incineration which led to a high calcium (Ca) content of fly ash. The reported sources of $\mathrm{Pb}, \mathrm{Cd}$ and $\mathrm{Zn}$ in MSW include plastic, food waste, and paper products $[7,8]$. Zn usually condenses onto the surface of fly ash during incineration due to its low boiling point. Various methods of treating MSWI fly ash such as solidification/stabilization (S/S), acid extraction, vitrification and sintering have been used to treat MSWI fly ash [9-14]. At present, the common treatment method for MSWI fly ash in Taiwan is the cement-based stabilization/solidification $(\mathrm{S} / \mathrm{S})$ process. However, the $\mathrm{S} / \mathrm{S}$ process generally increases the mass of fly ash to $145 \%$ of its original mass [1] and consequently limits the landfill capacity. Treatment methods capable of both environmental stabilization and resources' recovery should be considered. The wet extraction processes using various reagents [15-19] to achieve fly ash stabilized and metals' recovery have been investigated. However, most of the literatures focuses on the leaching of metals in MSWI fly ash and discusses the effects of experimental conditions such as reaction time, temperature, leaching reagents used, and the liquid-to-solid ratio. In this study, a novel process aiming for the mass reduction and metal recovery of MSWI fly ash was proposed. Firstly, a water-washing process was applied to dissolve soluble salts of 
potassium $(\mathrm{K})$, sodium $(\mathrm{Na})$, and Ca from fly ash and the wash-out leachate was then treated by ion exchange [20] to recover $\mathrm{Ca}$. Secondly, an acid-leaching process was applied to extract $\mathrm{Zn}$ from the residues after water-washing and the leachate was then treated by ion exchange [20] to recover $\mathrm{Zn}$.

\section{Materials and Methods}

\subsection{MSWI Fly Ash}

The MSWI fly ash used in this study came from an incineration plant in southern Taiwan. Grab samples of the ash were collected from the bag filter. The fly ash sample was mixed with a blender for $30 \mathrm{~s}$ in the laboratory to ensure that the samples became homogeneous. The coning and quartering method was used to reduce the sample weight to $2 \mathrm{~kg}$. The fly ash samples were passed through a sieve and the fraction smaller than $0.59 \mathrm{~mm}$ in diameter was collected and used in the following experiments. The elemental compositions of the fly ash was determined by acid digestion [21]. A $0.1 \mathrm{~g}$ ground sample was digested using aqua regia at $100{ }^{\circ} \mathrm{C}$ for $30 \mathrm{~min}$. After cooling and filtration, the composition of the filtrate was determined using an inductively coupled plasma-optical emission spectrometry (ICP-OES) (Optima 8300DV, PerkinElmer, Santa Clara, CA, USA). All the analyses were run in duplicate and the mean values were considered. The results were found to vary within $3 \%$. The mineralogical composition of the fly ash samples were analyzed by an X-ray diffractometer (XRD-RAPID II, Rigaku, Woodlands, TX, USA) to examine the mineral phases of the sample. The morphological images of the fly ash samples were observed byscanning electron microscopy (SEM, JSM-5610LV, Electron Optics Laboratory, Akishima, Tokyo, Japan) after Au coating.

\subsection{Water Washing}

The original fly ash sample was first washed with distilled water to remove the soluble salts. A dried fly ash sample was mixed with distilled water at different liquid/solid (L/S) ratios of (20-50):1 (in mL:g) and stirred in a beaker at room temperature. Samples of the suspension were taken at different time intervals up to $2.5 \mathrm{~h}$. The sample was vacuum filtrated and $\mathrm{Ca}$ in the filtrate was analyzed by the ICP/OES spectrometer. All the filtrates were collected and used in the subsequent ion exchange experiments. The filtration cake was dried to constant weight and analyzed by using X-ray diffractometer.

\subsection{Ca Recovery by Ion Exchange}

\subsubsection{Resin}

We examined several commercial resins for their suitability for Ca separation and a commercial weak acid chelating resin, IRC748, produced by Rohm and Haas appears to be very promising for this purpose. This resin is an iminodiacetic acid chelating cation exchange resin with high selectivity for heavy metal cations. The selectivity is achieved by the iminodiacetic acid functionality chemically bound to a macroreticular resin matrix as shown in Figure 1. Metal ions usually bind with one nitrogen and two oxygen atoms. The sodium form of the resin was used as received in this study.

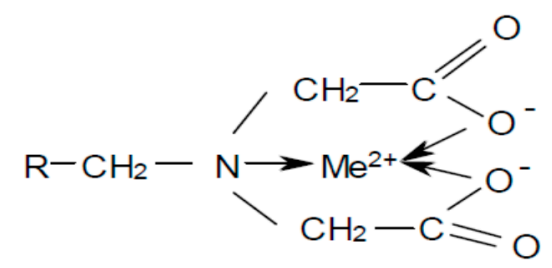

Figure 1. Molecular structure of the IRC748 resin. 


\subsubsection{Column Experiments}

The recovery of Ca using ion exchange was carried out via the column operation. A $10 \mathrm{~cm}$-long and $2.5 \mathrm{~cm}$ in diameter glass column was filled with $45 \mathrm{~mL}$ of the resin. The feed liquor was added to the top of the column at a constant flow rate and room temperature for column loading. Samples of the column effluent were taken from the bottom of the column periodically and the metal concentrations were analyzed to construe the breakthrough curves. The loaded column was then eluted by passing $\mathrm{HCl}$ through the column at a fixed flow rate. The elution curves were constructed in the same way as the breakthrough curves.

\subsection{Acid Leaching}

Acid leaching was applied to the water-washed fly ash for $\mathrm{Zn}$ extraction. Then, $10-40 \mathrm{~g}$ dried pre-washed fly ash was mixed with $200 \mathrm{~mL}$ solution with a fixed $\mathrm{HCl}$ concentration at room temperature. Samples of the suspension were taken after $1 \mathrm{~h}$ magnetic stirring. The sample was vacuum filtrated and $\mathrm{Zn}$ in the filtrate was analyzed by the ICP/OES spectrometer. All the filtrates were gathered and used in the subsequent column experiments. The filtration cake was dried to constant weight and the percent solid dissolved was calculated.

\subsection{Zn Recovery by Ion Exchange}

\subsubsection{Resin}

We examined several commercial resins for their suitability for $\mathrm{Zn}$ separation and a commercial weak acid chelating resin, Dow M4195, produced by Rohm and Haas, appears to be very promising for this purpose. Dow M4195 consists of the bispicolylamine ligand supported by a polymeric backbone of styrene cross-linked with divinylbenzene. Bispicolyl amine is a heterocyclic polyamine with three nitrogen donor atoms, as shown in Figure 2. The resin was used as received in this study.

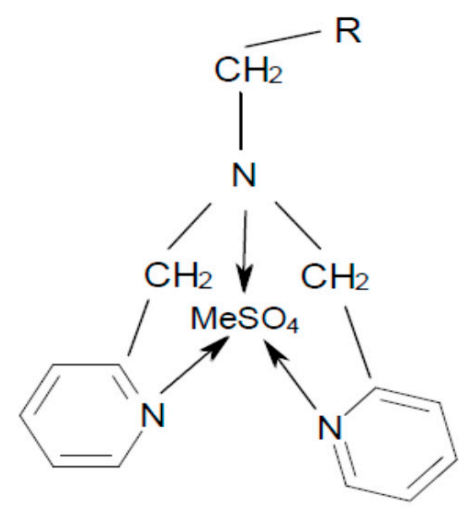

Figure 2. Molecular structure of the Dow M4195 chelating resin.

\subsubsection{Column Experiments}

The recovery of $\mathrm{Zn}$ using ion exchange was carried out via the column operation. A $10 \mathrm{~cm}$-long and $2.5 \mathrm{~cm}$ in diameter glass column was filled with $45 \mathrm{~mL}$ of the resin. The feed liquor was added to the top of the column at a fixed flow rate and room temperature for column loading. Samples of the column effluent were taken from the bottom of the column periodically and the metal concentrations were analyzed to construe the breakthrough curves. The loaded column was eluted by passing the first $\mathrm{HCl}$ solution, then the $\mathrm{NH}_{4} \mathrm{OH}$ solution through the column at a constant flow rate. The elution curves were constructed in the same way as the breakthrough curves. 


\section{Results}

\subsection{Characteristics of Fly Ashes}

Before starting the study of metal recovery from fly ash, the total content of the elements in the fly ash sample was required. The results for eight major elements are shown in Table 1. The major elements contained in fly ash are: $17.14 \% \mathrm{Ca}, 6.01 \% \mathrm{Na}, 3.22 \% \mathrm{~K}$, and notably $1.30 \%$ of $\mathrm{Zn}$. CaO or $\mathrm{CaCO}_{3}$ are injected into furnace to neutralize the emission of acid gases such as $\mathrm{HCl}$ and $\mathrm{SO}_{\mathbf{x}}$ during MSW incineration which led to a high calcium content and alkalinity of fly ash. Due to the volatile nature of sodium and potassium, fly ash also contains quite a large amount of sodium and potassium chlorides which are enriched in the fly ash during incineration. Considering the large amounts of water soluble $\mathrm{Ca}, \mathrm{Na}$ and $\mathrm{K}$ salts in fly ash, a simple water washing pretreatment to remove the water soluble salts before further treatment is feasible. Table 1 indicates that fly ash contains harmful heavy metal such as $\mathrm{Zn}, \mathrm{Pb}, \mathrm{Cu}$, and $\mathrm{Cd}$. Figure 3a shows the SEM images of the fly ash before water washing. An agglomerated structure was observed in the SEM image of the original fly ash. The fly ash particles were highly agglomerated and the small particles were coated on the surface of the large particles, forming agglomerates. The XRD diffraction results of the original fly ash was shown in Figure 4. We identified that the main crystal phases of fly ash include $\mathrm{Ca}_{6}\left(\mathrm{SiO}_{2}\right)\left(\mathrm{Si}_{2} \mathrm{O}_{7}\right)(\mathrm{OH})_{2}$ and $\mathrm{Na}_{2} \mathrm{Ca}_{5}\left(\mathrm{SO}_{4}\right) \cdot 3 \mathrm{H}_{2} \mathrm{O}$.

Table 1. Chemical contents of 8 elements in the municipal solid waste incinerator (MSWI) fly ash (\%).

\begin{tabular}{cc}
\hline Composition & Wt.\% \\
\hline $\mathrm{Ca}$ & 17.14 \\
$\mathrm{Na}$ & 6.01 \\
$\mathrm{~K}$ & 3.22 \\
$\mathrm{Mg}$ & 1.74 \\
$\mathrm{Zn}$ & 1.30 \\
$\mathrm{~Pb}$ & 0.31 \\
$\mathrm{Cu}$ & 0.08 \\
$\mathrm{Cd}$ & 0.01 \\
\hline
\end{tabular}

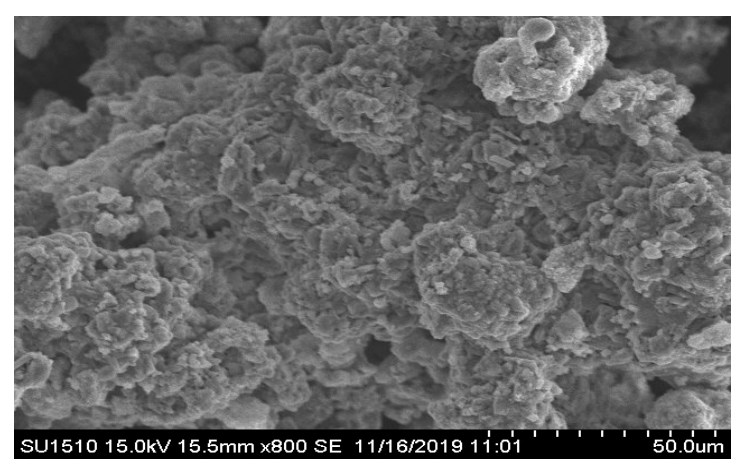

(a)

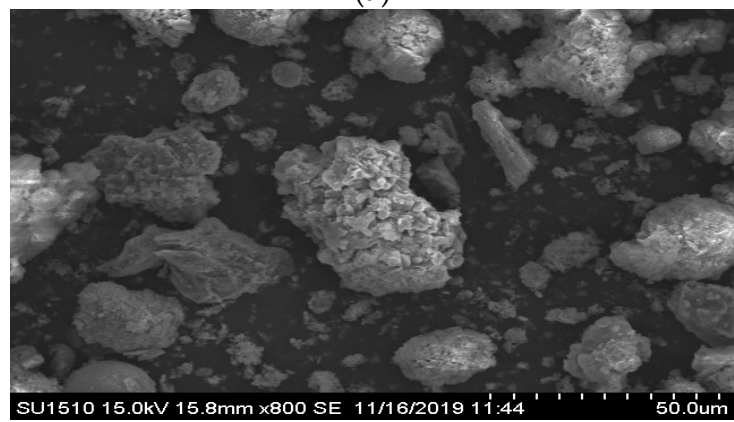

(b)

Figure 3. SEM micrographs of the MSWI fly ash (a) before and (b) after water washing. 




Figure 4. XRD diffraction pattern of the MSWI fly ash before and after washing.

\subsection{Water Washing}

Considering the large amounts of water soluble $\mathrm{Ca}, \mathrm{Na}$ and $\mathrm{K}$ salts in fly ash, a simple water washing pretreatment to remove the water soluble salts before further treatment is feasible. Figure 5 displays the effect of washing time on the solid-dissolved ratio for fly ash washing at the L/S ratio of 30 . It was observed that the soluble salts in fly ash dissolves rapidly during water washing and the solubility attained a maximum value of $30 \%$ before $0.5 \mathrm{~h}$. Extended washing resulted in a slightly decreased solubility of fly ash, presumably due to the re-precipitation of salts. Figure $3 b$ shows the SEM images of the fly ash after water washing. A de-agglomerated structure was observed in the SEM image of the washed fly ash. The fly ash particles were de-agglomerated due to the dissolution of cementing salts. The XRD diffraction results shown in Figure 4 provide a comparison between the crystal phases identified in the raw fly ash and the water-washed fly ash and showed that some peaks of the water-soluble salts were weakened in the washed ash. The results of fly ash pre-washing using various volumes of water mixed with a fixed amount of fly ash (L/S of 5 to $30 \mathrm{v} / \mathrm{w}$ ) are displayed in Figure 6. The results indicate that the increase in washing water volume increased the solubility of the salts in fly ash and it was found that a washing efficiency of $30 \%$ fly ash dissolved was obtained at a L/S (v/w) of 30. Although a higher $\mathrm{L} / \mathrm{S}$ ratios is favorable for the dissolution of salts in fly ash, a L/S ratio of 30:1 is recommended, considering both the washing efficiency and water conservation. The $\mathrm{Ca}$ released in the wash water could be recovered as a source of $\mathrm{CaO}$ and the results of $\mathrm{Ca}$ released for pre-washing using different volumes of water are shown in Figure 7. The extraction of Ca generally increases with an increasing $\mathrm{L} / \mathrm{S}$ ratio and reaches a maximum value $(25 \mathrm{wt} . \%)$ at a $\mathrm{L} / \mathrm{S}(\mathrm{v} / \mathrm{w})$ of 40 . Further increase in the L/S ratio slightly reduces the extraction amount of $\mathrm{Ca}$, presumably because that part of the extracted Ca was re-precipitated in the solution containing $1400 \mathrm{ppm}$ Ca. Based on the above results, water washing with experimental conditions of an L/S of $30(\mathrm{v} / \mathrm{w})$ and $0.5 \mathrm{~h}$ reaction time would give a $30 \%$ solid dissolved rate and $23 \%$ Ca extraction.



Figure 5. Dissolution of fly ash with water at liquid/solid (L/S) 30 for different time periods. 


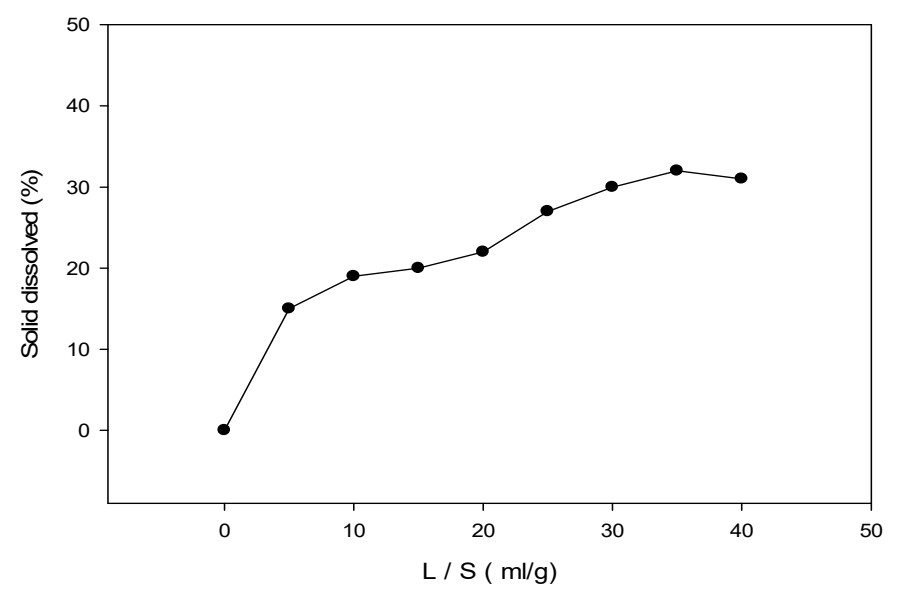

Figure 6. Effect of liquid/solid ratio on dissolution efficiency during water washing.

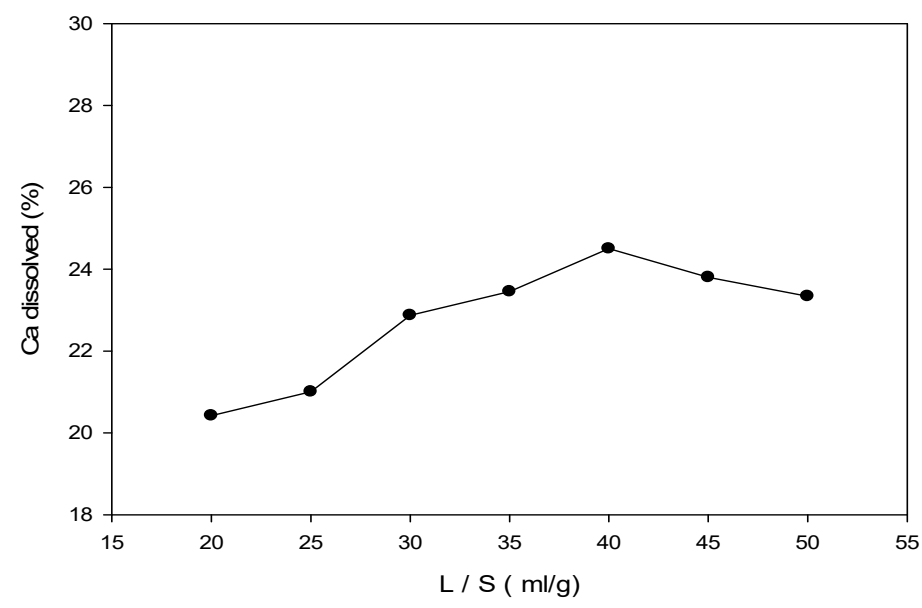

Figure 7. Effect of liquid/solid ratio on Ca extraction during water washing.

\subsection{Ca Recovery Using Ion Exchange}

The filtrate collected from water washing containing $1300 \mathrm{ppm} \mathrm{Ca} \mathrm{(pH} \mathrm{12)} \mathrm{wAS} \mathrm{adjusted} \mathrm{to} \mathrm{pH} 7$ by adding $5 \mathrm{~N} \mathrm{HCl}$ solution. In the column experiments, the feed solutions with $\mathrm{pH} 7$ and 12 were added to the top of the column filled with the IRC748 resins at a fixed flow rate and room temperature. The Ca concentration in the column effluent $(C)$ was compared to the Ca concentration in the feed $\left(\mathrm{C}_{0}\right)$. The $\mathrm{C} / \mathrm{C}_{0}$ ratio versus the dimensionless effluent volume (bed volume, $\mathrm{BV}$ ) were used to construct the breakthrough curves. Figure 8 shows the breakthrough curves for $\mathrm{Ca}$ at $\mathrm{pH} 7$ and 12 . It is observed that the chelating resin IRC748 shows a high affinity for Ca ions at basic conditions. The breakthrough volume changed from $12 \mathrm{BV}$ to $20 \mathrm{BV}$ when the $\mathrm{pH}$ was varied from 7 to 12 . Due to the presence of carboxylate groups, the dissociation of iminodiacetate functional groups of IRC748 is dictated by $\mathrm{pH}$. At $\mathrm{pH}=12$, all carboxylate groups are deprotonated, therefore, $\mathrm{Ca}^{2+}$ was adsorbed preferentially by IRC748 and separated from the coexisting $\mathrm{Na}^{+}, \mathrm{K}^{+}$ions. The amount of Ca adsorbed in the IRC748 resin column from feed containing $1300 \mathrm{mg} / \mathrm{L} \mathrm{Ca}$ before the breakthrough of Ca was found to be $39 \mathrm{~g} / \mathrm{L}_{\text {resin. }}$. The column elution was immediately conducted after the completion of the column loading. Figure 9 shows the elution curves for Ca loaded IRC748 resin using $1 \mathrm{~N}$ and $3 \mathrm{~N} \mathrm{HCl}$ respectively. Results indicated that $\mathrm{Ca}$ loaded IRC748 resin was well eluted with $3 \mathrm{~N} \mathrm{HCl}$ solution at a fixed flow rate of $0.1 \mathrm{~mL} / \mathrm{min}$, and complete elution was achieved when around $9 \mathrm{BV}$ of eluent was applied. The maximum measured concentration of $\mathrm{Ca}$ in the eluted solution was $22 \mathrm{~g} / \mathrm{L}$ and a concentration ratio of 17 was achieved from feed containing 1300 ppm Ca. 


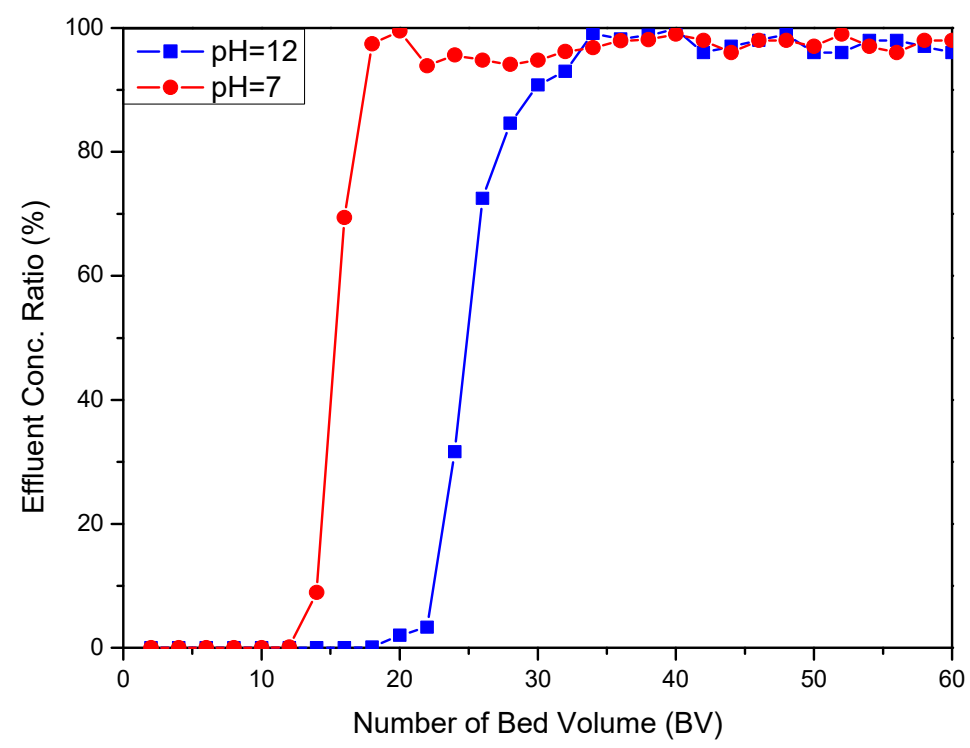

Figure 8. Breakthrough curves $\left(\mathrm{C} / \mathrm{C}_{0}\right.$ versus $\left.\mathrm{BV}\right)$ for $\mathrm{Ca}$ loading on IRC748 resin.

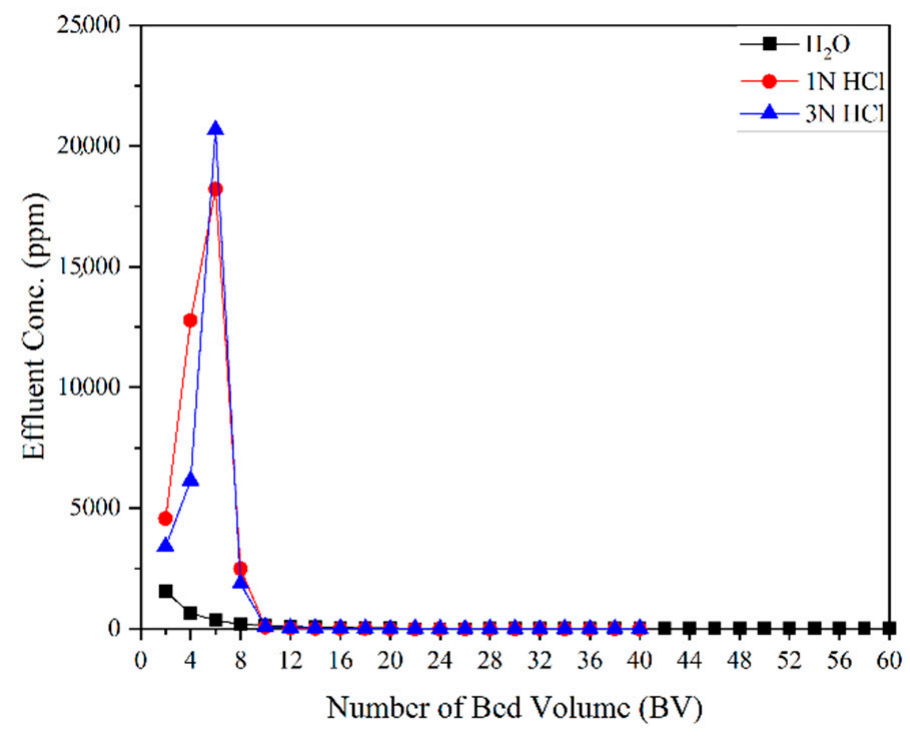

Figure 9. The elution curves for Ca eluted from the IRC748 resin.

\subsection{Acid Leaching}

The results of the acid leaching using different $\mathrm{S} / \mathrm{L}$ ratio $(10$ to $40 \mathrm{~g} / 200 \mathrm{~mL})$ and $\mathrm{HCl}$ concentrations $(1,3,5,7 \mathrm{~N})$ are presented in Figure 10. The results reveal that the decrease in $\mathrm{S} / \mathrm{L}$ ratio increased the solubility rate of the pre-washed ash and it was found that a solubility rate of $40 \%$ was achieved at $\mathrm{S} / \mathrm{L}(\mathrm{g} / 200 \mathrm{~mL})$ of 30 . Although the lower $\mathrm{S} / \mathrm{L}(\mathrm{g} / 200 \mathrm{~mL})$ ratios are favorable for the dissolution of pre-washed ash, an $\mathrm{S} / \mathrm{L}(\mathrm{g} / 200 \mathrm{~mL})$ of 30 is recommended, considering both the washing efficiency and water conservation. The effect of acid concentration on dissolution efficiency was examined at a $\mathrm{S} / \mathrm{L}$ of 10 to $40(\mathrm{~g} / 200 \mathrm{~mL})$, and a reaction time of $60 \mathrm{~min}$ at room temperature. It is found from Figure 10 that the dissolution ratio of pre-washed ash decreased with decreasing acid concentration at the highest $\mathrm{S} / \mathrm{L}$ ratio of $40(\mathrm{~g} / 200 \mathrm{~mL})$, presumably because that the amount of acid is limited at the condition of high solid loading. However, for lower S/L ratios (10-30), the amount of solid becomes the limited factor and no significant effects of acid concentration on the dissolution ratio were observed. Combining a water washing efficiency of $30 \%$ on raw ash and an acid leaching efficiency of $40 \%$ on pre-washed ash, a total of $58 \%$ mass reduction rate of fly ash was achieved. The effect of acid concentration $(1,3,5,7 \mathrm{~N} \mathrm{HCl})$ on $\mathrm{Zn}$ dissolution from the pre-washed ash was examined at $\mathrm{S} / \mathrm{L}$ of 10 to 40 and a reaction time of 
$60 \mathrm{~min}$ at room temperature. It was found from Figure 11 that the dissolution rate for $\mathrm{Zn}$ generally decreased with the increasing S/L ratio. For example, the $\mathrm{Zn}$ dissolution rates at the S/L ratio of 10 and 30 were found to be $100 \%$ and $80 \%$, respectively. Although the high acid concentrations are favorable for the $\mathrm{Zn}$ dissolution at an S/L ratio of 30, $1 \mathrm{~N} \mathrm{HCl}$ solution is recommended, considering both the dissolution efficiency $(80 \%)$ and acid conservation.



Figure 10. Effect of solid/liquid ratio and acid concentration on dissolution efficiency for water-washed fly ash.

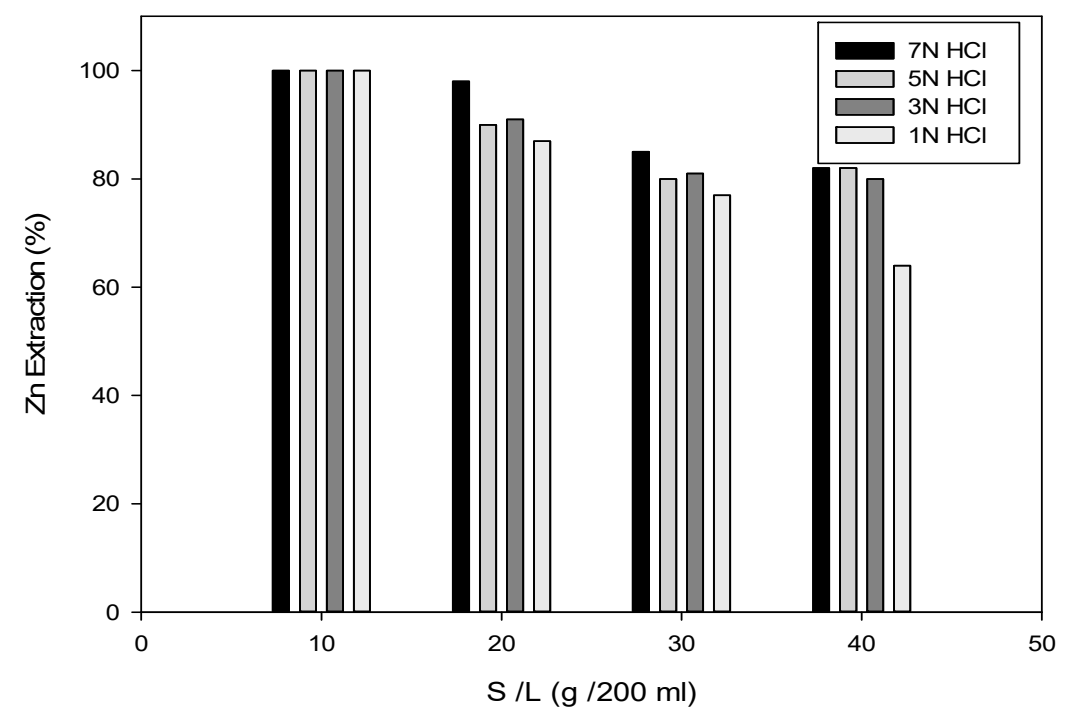

Figure 11. Effect of solid/liquid ratio and acid concentration on $\mathrm{Zn}$ extraction from water-washed fly ash.

\subsection{Zn Recovery Using Ion Exchange}

The filtrate collected from acid leaching containing 8200 ppm Ca and 1000 ppm Zn at pH 2 was used in the ion exchange experiments to recover $\mathrm{Zn}$. In the column experiments, the feed solution with pH 2 was added to the top of the column filled with the Dow M4195 resin at a fixed flow rate of 1.7 BV/h and room temperature. The $\mathrm{C} / \mathrm{C}_{0}$ ratio of $\mathrm{Ca}$ and $\mathrm{Zn}$ concentrations versus the dimensionless effluent volume (bed volume, BV) were used to construct the breakthrough curves. Figure 12 shows the breakthrough curves for $\mathrm{Ca}$ and $\mathrm{Zn}$. It can be seen that the breakthrough of $\mathrm{Ca}$ appeared at $5 \mathrm{BV}$, while the breakthrough of $\mathrm{Zn}$ did not happen until the volume of effluent reached 14 BV. Apparently, 
the affinity order of metals for Dow M4195 resin is $\mathrm{Zn}>\mathrm{Ca}$. In addition, the breakthrough curve for Ca indicates that a small portion (10\%) of Ca in the feed was continuously adsorbed by Dow M4195 during the column loading. Thus, the separation of $\mathrm{Zn}$ from Ca was not completed by Dow M4195 resin under the experimental conditions of column loading used in this study. The column elution was immediately conducted after the completion of the column loading. The difference in the affinities of Ca and Zn on Dow M4195 resin was utilized to separate the adsorbed Ca and Zn by conducting a chromatographic elution. Figure 13 shows the elution curves for $\mathrm{Ca}$ and $\mathrm{Zn}$ loaded Dow M4195 resin using $4 \mathrm{~N} \mathrm{HCl}$ and $4 \mathrm{M} \mathrm{NH}_{4} \mathrm{OH}$. The $4 \mathrm{~N} \mathrm{HCl}$ first eluted the adsorbed $\mathrm{Ca}$, and subsequent elution with $4 \mathrm{M} \mathrm{NH}_{4} \mathrm{OH}$ successfully eluted $\mathrm{Zn}$ from Dow M4195 resin. A Ca elution efficiency of $98 \%$ was achieved when around $8 \mathrm{BV}$ of eluent was applied. The maximum measured $\mathrm{Ca}$ concentration in the eluted solution was $10 \mathrm{~g} / \mathrm{L}$ with a purity of $97.5 \%$. The loaded $\mathrm{Zn}$ was well eluted with $4 \mathrm{M} \mathrm{NH}_{4} \mathrm{OH}$ solution by using $7 \mathrm{BV}$ solutions. An elution efficiency of $98 \%$ was achieved and the maximum concentration of $\mathrm{Zn}$ in the eluted solution was $6 \mathrm{~g} / \mathrm{L}$ with a purity of $98.7 \%$.

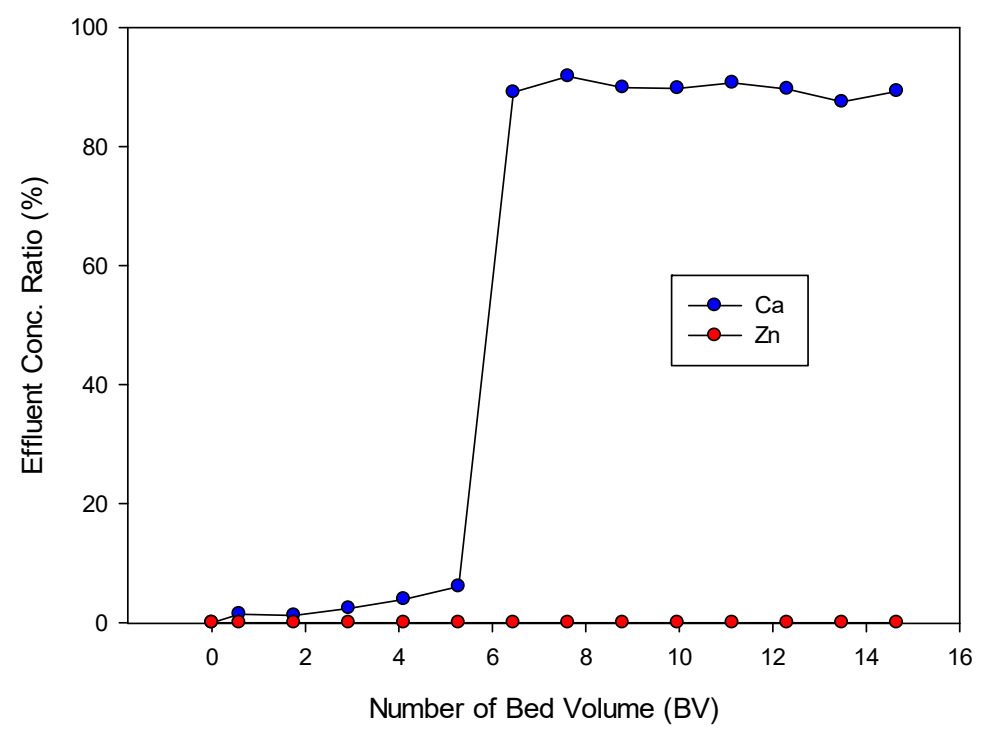

Figure 12. Breakthrough curves $\left(C / C_{0}\right.$ versus BV) for Ca and $\mathrm{Zn}$ loading on Dow M4195 resin.

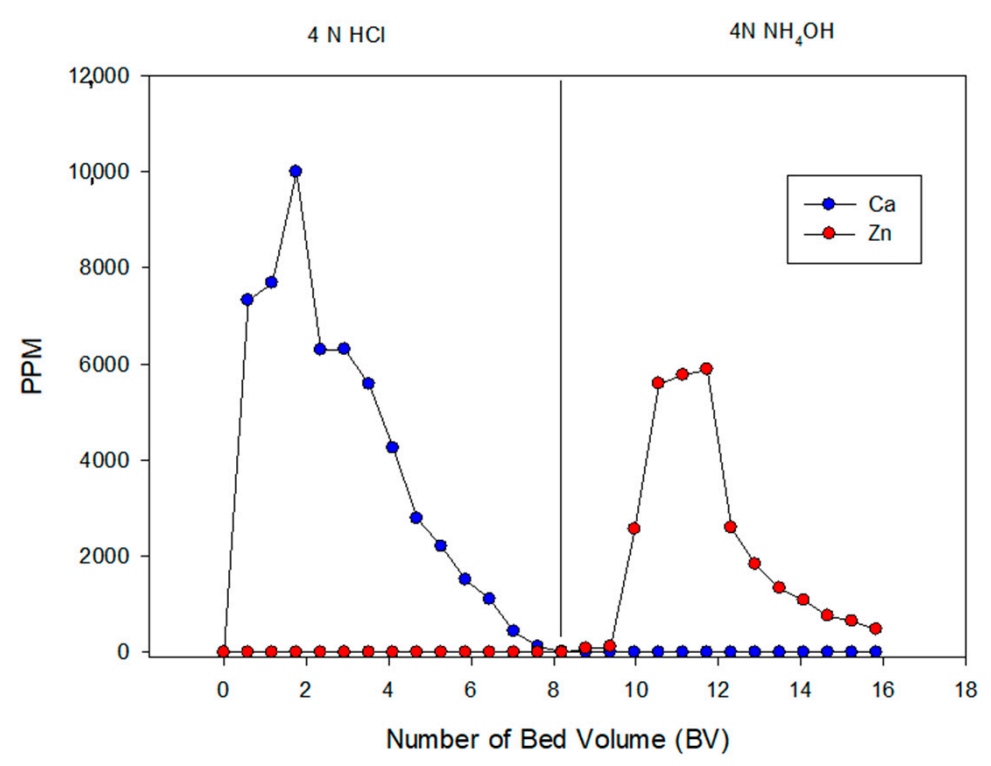

Figure 13. Chromatographic elution of Ca and Zn from Dow M4195 resin. 


\subsection{Recommended Process for Recovery of $\mathrm{Ca}$ and $\mathrm{Zn}$}

A proposed process for the washing of Ca and acid leaching of Zn from MSWI fly ash and the recovery of $\mathrm{Ca}$ and $\mathrm{Zn}$ from the leached solution using ion exchange is summarized in Figure 14. A water washing with an $\mathrm{L} / \mathrm{S}$ of $30 \mathrm{v} / \mathrm{w}$ and $0.5 \mathrm{~h}$ reaction time gives about $30 \%$ solid dissolved rate and $23 \%$ Ca extraction. The filtrate was then treated by ion exchange to adsorb Ca. The loaded Ca is eluted with $3 \mathrm{~N} \mathrm{HCl}$ and the concentrated Ca solution is collected. The washed fly ash was further leached with $1 \mathrm{~N} \mathrm{HCl}$ at an $\mathrm{S} / \mathrm{L}$ ratio of 30 and $0.5 \mathrm{~h}$ reaction time. A $40 \%$ solid dissolved rate and $80 \%$ $\mathrm{Zn}$ dissolution were achieved. The filtrate was then treated by ion exchange to adsorb $\mathrm{Zn}$. The Ca and Zn loaded column was firstly eluted with $3 \mathrm{~N} \mathrm{HCl}$ to collect the concentrated Ca solution and secondly eluted with $4 \mathrm{M} \mathrm{NH}_{4} \mathrm{OH}$ to collect the concentrated $\mathrm{Zn}$ solution.

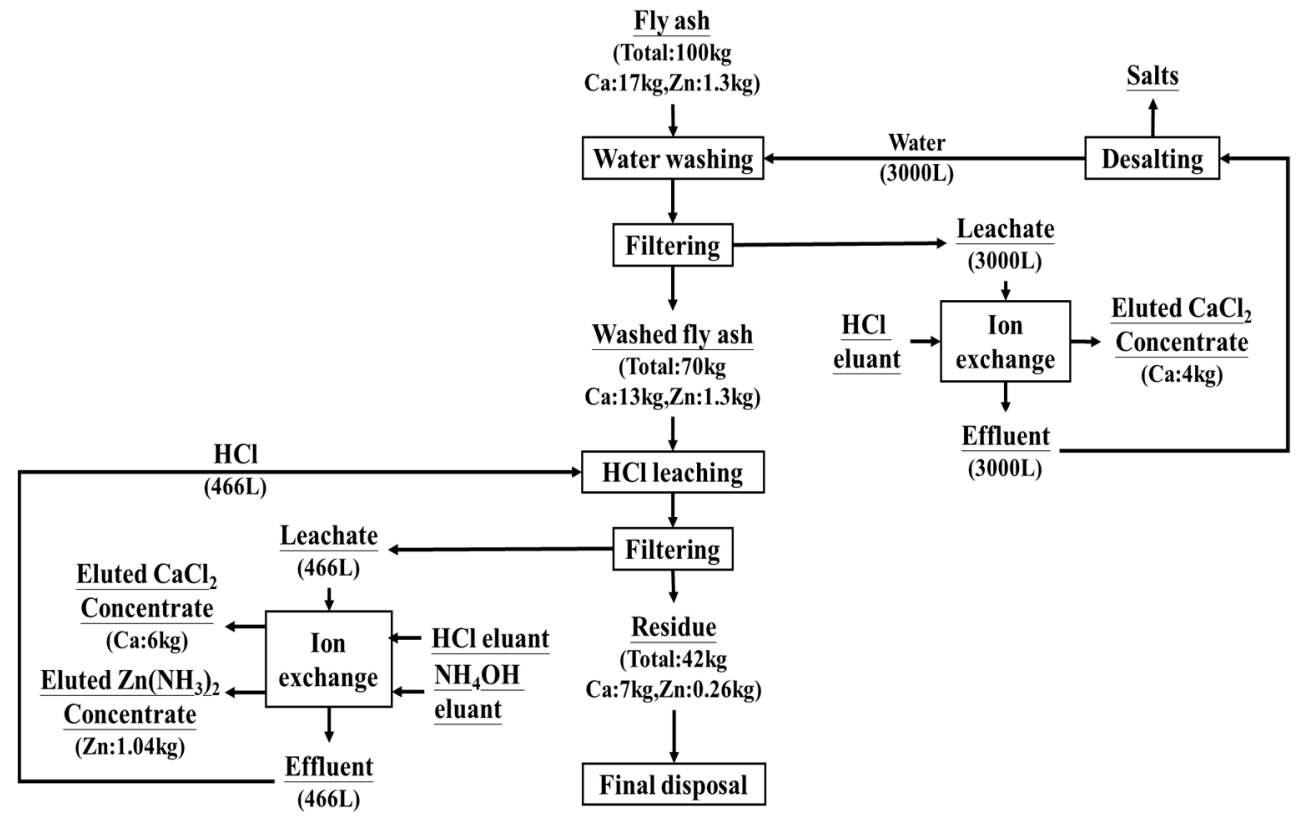

Figure 14. Proposed flow chart for the Ca and Zn recovery from MSWI fly ash.

\section{Conclusions}

This study indicated that Ca can be effectively and selectively recovered using a water washing and ion exchange process. Under optimum conditions, the 23\% Ca was recovered and a 30\% fly ash mass reduction rate was achieved in this stage. $\mathrm{Zn}$ in the water-washed fly ash was recovered using an acid leaching and ion exchange process. Under optimum conditions, $80 \% \mathrm{Zn}$ and an additional $35 \%$ Ca were recovered, and together with a further $28 \%$ fly ash mass reduction rate was achieved in this stage. The findings of this study demonstrated that this process integrating water washing, acid leaching and ion exchange can provide an alternative solution for MSWI fly ash treatment

Author Contributions: Y.-H.S. and envisioned and designed the research; S.-Y.Z. performed the data collection; Y.-H.S. and C.-P.Y. analyzed the results; Y.-H.S. wrote the original manuscript; C.-P.Y. and S.-Y.Z. reviewed the manuscript. All authors have read and agreed to the published version of the manuscript.

Funding: This research received no external funding.

Conflicts of Interest: The authors declare no conflict of interest.

\section{References}

1. Taiwan Environmental Protection Administration (EPA). Year Book of Environmental Protection Statistics; Taiwan EPA: Taipei, China, 2019.

2. Kirby, C.S.; Rimstidt, J.D. Mineralogy and surface properties of municipal solid waste ash. Environ. Sci. Technol. 1993, 27, 652-660. [CrossRef] 
3. Hjelmar, O. Disposal strategies for municipal solid waste incineration residues. J. Hazard. Mater. 1996, 47, 345-368. [CrossRef]

4. Rosen, C.J.; Bierman, P.M.; Olson, D. Swiss chard and alfalfa responses to soil amended with municipal solid waste incinerator ash: Growth and elemental composition. J. Agric. Food Chem. 1994, 42,1361-1368. [CrossRef]

5. Bierman, P.M.; Rosen, C.J. Phosphate and trace metal availability from sewage sludge incineration ash. J. Environ. Qual. 1994, 23, 822-830. [CrossRef]

6. Nagib, S.; Inoue, K. Recovery of lead and zinc from fly ash generated from municipal incineration plants by means of acid and/or alkaline leaching. Hydrometallurgy 2000, 56, 269-292. [CrossRef]

7. Zhao, L.J.; Zhang, F.S.; Wang, K.S.; Zhu, J.X. Chemical properties of heavy metals in typical hospital waste incinerator ashes in China. Waste Manag. 2008, 29, 1114-1121. [CrossRef] [PubMed]

8. Liu, F.; Liu, H.-Q.; Wei, G.-X.; Zhang, R.; Zeng, T.-T.; Liu, G.-S.; Zhou, J.-H. Characteristics and treatment methods of medical waste incinerator fly ash: A review. Processes 2018, 6, 173. [CrossRef]

9. Sakai, S.; Hiraoka, M. Municipal solid waste incinerator residue recycling by thermal process. Waste Manag. 2000, 20, 249-258. [CrossRef]

10. Wey, M.Y.; Liu, K.Y.; Tsai, T.H.; Chou, J.T. The thermal treatment of the fly ash from municipal solid waste incinerator with rotary kiln. J. Hazard. Mater. 2006, 137, 981-989. [CrossRef] [PubMed]

11. Cheng, T.W.; Ueng, T.H.; Chen, Y.S.; Chiu, J.P. Production of glass-ceramic from incinerator fly ash. Ceram. Int. 2002, 28, 779-783. [CrossRef]

12. Aloisi, M.; Karamanov, A.; Pelino, M. Sintered glass-ceramic from municipal solid waste incinerator ashes. J. Non-Cryst. Solids 2004, 345-346, 192-196. [CrossRef]

13. Mangialardi, T. Sintering of MSW fly ash for reuse as a concrete aggregate. J. Hazard. Mater. 2001, 87, 225-239. [CrossRef]

14. Wang, K.S.; Chiang, K.Y.; Perng, J.K.; Sun, C.J. The characteristics study on sintering of municipal solid waste incinerator ashes. J. Hazard. Mater. 1998, 59, 201-210. [CrossRef]

15. Hong, K.J.; Tokunaga, S.; Ishigami, Y.; Kajiguchi, T. Extraction of heavy metals from MSW incinerator fly ash using saponins. Chemosphere 2000, 14, 345-352. [CrossRef]

16. Katsuura, H.; Inoue, T.; Hiraoka, M.; Sakai, S. Full-scale plant study on fly ash treatment by the acid extraction process. Waste Manag. 1996, 16, 491-499. [CrossRef]

17. Zhang, F.; Itoh, H. Extraction of metals from municipal solid waste incinerator fly ash by hydrothermal process. J. Hazard. Mater. 2006, 136, 663-670. [CrossRef] [PubMed]

18. Zhang, F.; Itoh, H. A novel process utilizing subcritical water and nitrilotriacetic acid to extract hazardous elements from MSW incinerator fly ash. Sci. Total Environ. 2006, 369, 273-279. [CrossRef] [PubMed]

19. Ishigaki, T.; Nakanishi, A.; Tateda, M.; Ike, M.; Fujita, M. Bioleaching of metal from municipal waste incineration fly ash using a mixed culture of sulfur-oxidizing and iron-oxidizing bacteria. Chemosphere 2005, 60, 1087-1094. [CrossRef] [PubMed]

20. Cheng, T.-H.; Liu, C.-J.; Tsai, T.-Y.; Shen, Y.-H. A process for the recovery of gallium from gallium arsenide scrap. Processes 2019, 7, 921. [CrossRef]

21. Li, X.B.; Ye, J.J.; Liu, Z.H.; Qiu, Y.Q.; Li, L.J.; Mao, S.; Wang, X.C.; Zhang, Q. Microwave digestion and alkali fusion assisted hydrothermal synthesis of zeolite from coal fly ash for enhanced adsorption of Cd(II) in aqueous solution. J. Cent. South Univ. 2018, 25, 9-20. [CrossRef]

Publisher's Note: MDPI stays neutral with regard to jurisdictional claims in published maps and institutional affiliations.

(C) 2020 by the authors. Licensee MDPI, Basel, Switzerland. This article is an open access article distributed under the terms and conditions of the Creative Commons Attribution (CC BY) license (http://creativecommons.org/licenses/by/4.0/). 